\title{
MIR106A Gene
}

National Cancer Institute

\section{Source}

National Cancer Institute. MIR106A Gene. NCI Thesaurus. Code C81773.

This gene is involved in the regulation of gene expression and is proposed to act as an oncogene in a broad variety of leukemias as well as colon, pancreatic and prostate carcinomas. 